\title{
SEMANTIC CONNECTION : RANCANGAN PLATFORM KOMUNIKASI PADA SMART OBJECT
}

\author{
Iwan Kurnianto Wibowo \\ Program Studi Teknik Komputer, Politeknik Elektronika Negeri Surabaya \\ *Corresponding author, e-mail: eone@pens.ac.id
}

\begin{abstract}
Abstrak - Untuk memberikan pengalaman bermain lebih mendalam, perlu disusun kerangka permainan yang memanfaatkan media smart object sebagai media interaksi dengan skenario yang bervariasi. Pada penelitian sebelumnya telah dibangun sebuah media permainan berupa smart object. Smart object secara fisik terintegrasi dengan sensor, prosesor, dan jaringan. Smart object mampu merasakan, menafsirkan apa yang terjadi dengan dirinya dan lingkungan sekitar, bereaksi, berinteraksi dengan objek lainnya dan bertukar informasi dengan pengguna. Media interaksi erat kaitannya dengan platform komunikasi yang digunakan. Makalah ini menyajikan platform komunikasi pada smart object yang telah dibangun. Platform komunikasi meliputi mekanisme smart object dalam melayani interaksi dengan smart object lain dan komunikasi dengan server. Smart object berfungsi sebagai perangkat masukan dan keluaran universal berbasis sistem embedded yang ditanamkan sebuah protokol dalam berkomunikasi. Sehingga banyak skenario permainan yang dapat diimplementasikan. Komunikasi data antara smart object dan server dilakukan secara nirkabel dan full duplex, antara jalur penerimaan dan pengiriman data terpisah dan bekerja secara bersamaan. Pengiriman data point to multipoint mengadopsi topologi bintang. Server terhubung langsung ke masing-masing smart object. Pengiriman data antara sebuah smart object ke server menghasilkan tingkat kesalahan hingga $0.15 \%$. Ketika ada tiga smart object yang berkomunikasi dengan server maka tingkat kesalahan meningkat hingga $2.77 \%$.
\end{abstract}

\section{Kata Kunci : Pengalaman permainan, Smart object, Platform komunikasi}

\begin{abstract}
To provide a better gaming experience, it needs to design a game framework using smart object media as interaction media with various scenarios. In previous researchs have built a game media such as a smart object. Smart objects are physically integrated with the sensor, processor, and network. Smart object able to sense, interpret what is happening with him and their surroundings, reacting, interacting with other objects and exchanging information with the user. Media interaction is closely related to the communication platforms used. This paper presents a communication platform on smart object. The communication platform provides mechanisms of smart object to serve the interaction with other smart object and communicates with server. The smart object functions as universal input and output device based embedded systems that have a communication protocol. So that many game scenarios can be implemented. Data communication between the smart object and the server is done wirelessly and full duplex, between data receiving and trasmitting lines are separated and worked simultaneously. Point to multipoint data transmission adopts star topology. The server is connected directly to each smart object. Data transmission between a smart object to the server generates an error rate of up to $0.15 \%$. When there are three smart object that communicates with the server, the error rate increased to $2.77 \%$.
\end{abstract}

\section{Keywords : Gaming Experience, Smart Object, Communication Platform}

Copyright (C) 2016 JNTE. All rights reserved

\section{PENDAHULUAN}

Dengan meningkatnya dunia permainan, akan membawa pengguna ke tingkat pengalaman permainan baru, dimana teknologi akan mendekatkan pengguna untuk berinteraksi dengan perangkat keras. Pengalaman permainan melibatkan berbagai aktifitas. Aktifitas yang paling utama adalah bagaimana pengguna berinteraksi dengan permainan itu sendiri. Interaksi dalam permainan cenderung menggunakan sebuah joystick. Sekarang ada banyak permainan fisik yang menggabungkan perangkat keras dengan teknologi sensor sebagai perangkat masukan seperti permainan helikopter dengan pengendali jarak jauh, robot dengan senapan, dan mobil yang dapat dikendalikan dengan remote. 
Penggunaan perangkat masukan dan keluaran khusus seperti joystick dan sarung tangan elektronik, memungkinkan pengguna menerima umpan balik dari aplikasi komputer dalam bentuk sensasi sentuhan tubuh [1]. Remote Nintendo Wii menjanjikan tidak hanya sebagai masukan perangkat permainan tetapi juga sebagai perangkat yang mampu mengintegrasikan rehabilitasi klinis di rumah dengan melakukan latihan sistem terapi [2]. Penggunaan accelerometer pada remote Nintendo Wii akan meningkatkan kehandalan simulasi terapi pada komputer[3].

Meskipun sudah mengedepankan penggunaan teknologi, perangkat keras seperti remote Nintendo Wii hanya berfungsi sebagai masukan. Sehingga pengguna lama-lama akan mengalami kebosanan dalam bermain karena kurang memberikan pengalaman permainan yang imersif. Pengguna tidak merasakan bahwa permainan itu nyata. Pada penelitian ini secara global disajikan sebuah user interface pada permainan menggunakan media objek yang alur permainannya diatur dalam sebuah semantic connection. Melalui media objek ini, diharapkan permainan akan mempresentasikan kejadian sesungguhnya.

Objek-objek sederhana (lampu, kursi, buku dan lain-lain) mempunyai interface. Sebagai contoh, lampu mempunyai interface secara fisik yang terdiri dari bentuk, ukuran, komposisi dan berat. Interface tampilan visual secara estetika terdiri dari kecerahan, warna dan tekstur. Interface fungsional dengan API yang digunakan orang untuk menyalakan dan mematikan lampu. Interface daya untuk hubungan ke jala-jala listrik. Beberapa interface tersebut merupakan identitas implisit sehingga orang dapat mengatakan dua lampu berbeda meskipun terlihat sama.

Objek konvensional biasanya tidak begitu cerdas, tidak mempunyai identitas secara eksplisit dan tidak dapat berkomunikasi[4]. Smart object secara fisik terintegrasi dengan sensor, prosessor, dan jaringan [5]. Smart object mampu merasakan, menafsirkan apa yang terjadi pada dirinya dan lingkungan sekitar, bereaksi, berinteraksi dengan objek lain dan bertukar informasi dengan pengguna. Paradigma smart object didasarkan pada konsep ubiquitous computing [6], yang memungkinkan interaksi dengan smart object lain secara virtual dimanapun dan kapanpun, dan berpotensi mengubah cara manusia hidup dan bekerja dalam sebuah komunitas objek. Smart object dibangun dari suatu objek biasa yang ditanamkan beberapa sensor dan diatur oleh semantic connection. Semantic connection memungkinkan perubahan objek sehari-hari menjadi smart object yang dapat memahami dan bereaksi terhadap lingkungan sekitar. Kesulitan smart object dalam menafsirkan apa yang terjadi pada dirinya adalah proses ekstraksi informasi yang berarti pembacaan sensorik[7].

\section{TINJAUAN PUSTAKA}

Lingkungan cerdas terdiri dari beberapa perangkat dalam suatu jaringan yang mempunyai suatu koneksi ke dunia fisik. Tak seperti smart devices, perangkat yang berada dalam lingkungan cerdas biasanya menjalankan tugas tunggal yang telah ditetapkan, misalnya, sistem pendeteksi keberadaan manusia di ruangan untuk menghemat daya kipas angin. Komponen lingkungan yang tertanam dapat dirancang secara otomatis merespon atau mengantisipasi interaksi pengguna menggunakan iHCI (implisit Human Computer Interaction), misalnya seseorang melakukan aktivitas di ruangan, kemudian kipas angin akan menyala.

Perangkat lingkungan cerdas mendukung beberapa jenis interaksi dengan lingkungan seperti lingkungan fisik sebagai berikut:

1. Tagging dan near field communication. Sebagai contoh adalah RFID atau Infrared yang ditanamkan pada objek fisik.

2. Sensing dan monitoring lingkungan. Transduser mengambil informasi berupa data mentah dari lingkungan fisik. Informasi yang dapat diambil adalah kemiringan, posisi, suhu dan lain lain. Dengan tersedianya berbagai informasi tersebut diharapkan smart object mampu menafsirkan apa yang terjadi pada dirinya.

3. Pengendalian dunia fisik. Pengendali membutuhkan sensor untuk menafsirkan sesuatu yang terjadi dan memberikan keluaran sesuai dengan kejadian tersebut.

Lingkungan cerdas menggunakan komponen yang tertanam. Sistem tertanam (embedded) biasanya memberikan dukungan kendali dan pemantauan untuk sistem yang lebih besar. Perangkat lingkungan cerdas mempunyai ukuran 
yang bervariasi, tergantung dari seberapa besar tingkat mobilitas. Ukuran dari komponen perangkat keras juga berperan. Dengan menggunakan komponen yang berukuran kecil, maka akan sangat mudah untuk merancang bentuk perangkat lingkungan cerdas.

\subsection{Smart Interaction}

Dasar interaksi biasanya melibatkan dua pihak yaitu pengirim dan penerima informasi. Pengirim informasi mengetahui alamat penerima informasi. Struktur dan makna informasi telah disepakati di awal. Begitu pula dengan urutan informasi yang dikirimkan. Isi dari informasi dapat bervariasi. Ada dua jenis interaksi dasar, yaitu sinkron dan asinkron.

1. Interaksi sinkron. Protokol interaksi terdiri dari flow control dua pesan, meliputi pengiriman permintaan kemudian diterima respon balasan. Pengirim mengirim permintaan pesan ke penerima tertentu dan menunggu balasan diterima, seperti client membuat permintaan ke server dan mendapatkan respon. Pengirim menunggu acknowledgement dari penerima untuk memastikan pesan telah diterima.

2. Interaksi asinkron. Protokol interaksi terdiri dari pesan tunggal yang tidak menggunakan flow control, pengirim mengirimkan pesan ke penerima tanpa diketahui bahwa penerima akan menerima pesan atau jika akan ada balasan berikutnya. Pengiriman pesan dilakukan secara terus menerus dan tidak memperhatikan bahwa terjadi sesuatu yang tidak dikehendaki seperti buffer penuh atau pesan belum sepenuhnya diproses.

Interaksi sinkron dan asinkron dianggap sebagai bagian dari fungsi komunikasi terdistribusi.

\subsection{Smart Object}

Baru-baru ini dikenalkan sebuah gagasan di ranah inteligensia tentang produk cerdas. Produk cerdas mampu beradaptasi terhadap situasi dan pengguna [8]. Smart object dipandang dari dua perspektif yaitu smart object mempunyai orientasi sistem dan kejelian smart object dapat mengambil tindakan berdasarkan informasi yang dikumpulkan sebelumnya. Kebanyakan karya terbaru smart object telah difokuskan pada aspek teknis (hardware platform, infrastruktur software dan sebagainya) dan skenario aplikasi [9].

Smart object secara fisik dimanipulasi sebagai kelompok untuk berinteraksi dengan informasi digital dan media. Smart object menelaah bagaimana teknologi jaringan sensor digabungkan dengan fitur dari GUI dan TUI untuk meningkatkan interaksi pengguna dan dunia digital.

\section{METODOLOGI}

\subsection{Desain Smart Object}

Pada penelitian ini, dirancang tiga buah smart object sebagai media interaksi. Masingmasing smart object mempunyai kemampuan untuk mengetahui kemiringan atau orientasi dan mengenali smart object lain yang berada di samping. Perancangan smart object ditunjukkan pada Gambar 1.

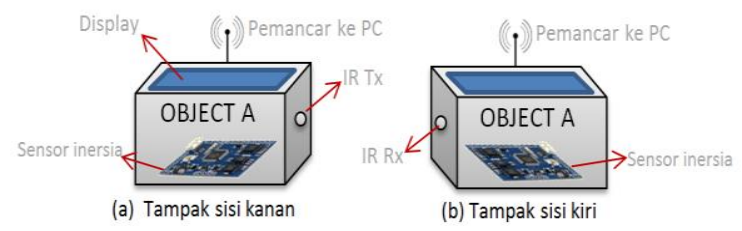

Gambar 1. Smart object (a) tampak sisi kanan, (b) tampak sisi kiri

Pada Gambar 1, ditunjukkan ada beberapa perangkat keras yang ditanamkan pada smart object. Sensor inersia digunakan untuk menghasilkan estimasi orientasi. Sensor infrared digunakan sebagai media interaksi antar smart object. Untuk memperoleh estimasi orientasi yang akurat, sederhana dan dapat diimplentasikan pada smart object berbasis sistem embedded, maka dilakukan penggabungan data sensor accelerometer dan gyroscope menggunakan metode Complementary Filter [10]. Interaksi yang dilakukan antar smart object bersifat satu arah.

\subsection{Protokol Komunikasi}

Jaringan sensor telah dikenal sebagai salah satu teknologi penting pada abad ke-21 [11]. Teknologi ini membuat ilmuwan berpikir bagaimana merealisasikan visi sebuah dunia yang penuh dengan sensor cerdas yang digunakan untuk mengumpulkan data dari beberapa objek yang terpisah. 
Pengiriman data dari smart object ke server dan sebaliknya dilakukan secara nirkabel menggunakan modul Xbee Pro. Komunikasi data menggunakan Xbee Pro dilakukan secara serial dengan modulasi FSK $2.4 \mathrm{GHz}$. Komunikasi data berjalan secara full duplex, antara jalur penerimaan dan pengiriman data terpisah dan bekerja secara bersamaan. Xbee sepenuhnya menggunakan protokol untuk komunikasi data yang menyediakan fitur handal dalam jaringan sensor nirkabel. Sehingga pengiriman data dipastikan aman.

Server menerima data masukan dari smart object berupa data sensor, yaitu orientasi dan identitas smart object lain yang berada di samping, seperti ditunjukkan pada Gambar 2. Selanjutnya server mengolah data dari smart object sesuai dengan skenario yang dirancang. Data keluaran yang dapat dikirimkan ke smart object adalah data tampilan dengan format yang ditentukan.

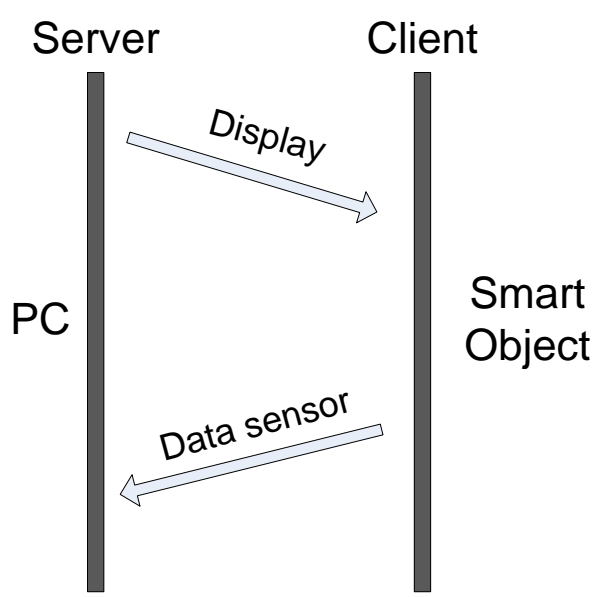

Gambar 2. Komunikasi data antara smart object dan server

Penelitian ini menggunakan pengiriman data point to multipoint dengan mengadopsi topologi bintang. Server terhubung langsung ke masing-masing smart object. Traffic data mengalir dari smart object ke server dan kembali lagi. Apabila terjadi gangguan pada salah satu jalur komunikasi smart object, maka jalur komunikasi smart object lainnya tidak mengalami gangguan. Pada topologi bintang semua perangkat berada dalam komunikasi langsung ke server (coordinator), dimana semua informasi data diarahkan [12].
Data hanya akan dikirim jika terjadi perubahan data supaya daya listrik menjadi hemat. Masing-masing smart object mengirimkan paket data ke server yang berisi identitas diri berupa header agar dikenali dari mana asal data tersebut. Gambar 3 menunjukkan format paket data yang dikirim dari salah satu smart object ke server. Paket data berisi karakter ASCII.

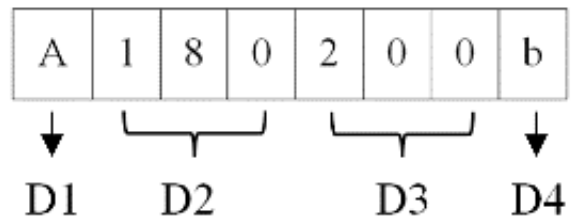

Gambar 3. Format paket data yang dikirim dari smart object ke server

Dimana D1 adalah header paket data, D2 adalah data roll, D3 adalah pitch dan D4 adalah identitas smart object yang berada di samping kiri. Identitas smart object yang berada di samping kiri juga digunakan sebagai tail paket data. Identitas smart object yang berada di samping diketahui menggunakan perangkat Near Field Communication berupa infrared.

Ketiga smart object menerima paket data yang dikirim oleh server, apabila paket data tersebut tidak berisi alamat yang sesuai, maka akan diabaikan. Hanya smart object dengan alamat yang sama akan merespon paket data tersebut. Sebuah smart object hanya mempunyai satu alamat yang berupa header paket data. Misalkan keluaran yang akan ditampilkan pada salah satu smart object seperti pada Gambar 4, maka format paket data yang dikirimkan ke smart object bersangkutan ditunjukkan seperti pada Gambar 6.

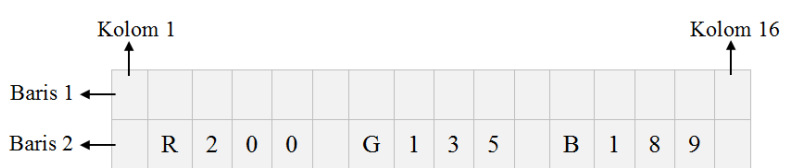

Gambar 4. Keluaran yang ditampilkan pada LCD smart object

Pada Gambar 5 ditunjukkan aturan yang digunakan dalam memberikan tampilan LCD. Jika ingin menampilkan data pada posisi tertentu, maka flag pada posisi itu bernilai "1" dan jika tidak ada tampilan maka bernilai "0". 


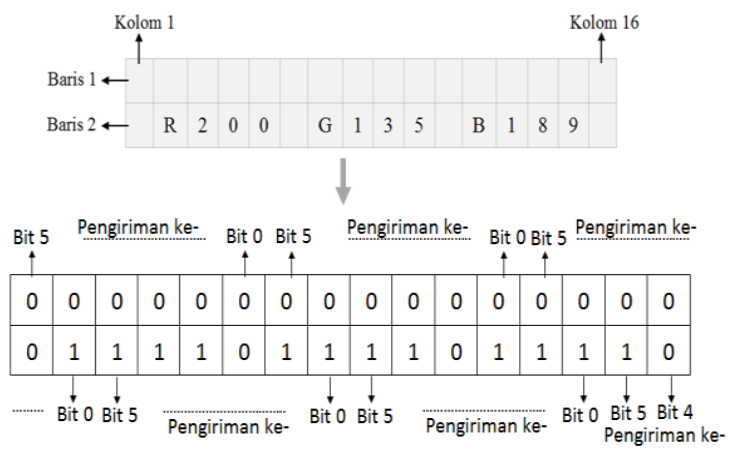

Gambar 5. Cara pemberian flag tampilan LCD smart object

Untuk tampilan LCD dengan luas dua baris dan enam belas jumlah kolom, diperlukan lebar data 32 bit dan dikirim menjadi enam kali pengiriman data serial. Dengan demikian jumlah pengiriman data yang ingin ditampilkan di LCD menjadi tidak pasti.

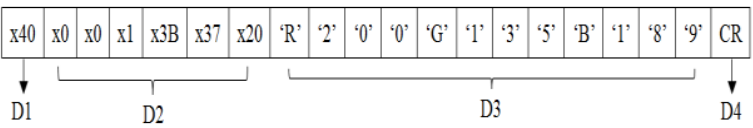

Gambar 6. Format paket data yang dikirim dari server ke smart object

Dimana D1 adalah header, D2 adalah flag posisi LCD, D3 adalah data yang ingin ditampilkan dan D4 adalah tail. Gambar 6 menyajikan paket data yang dikirim dari server ke smart object. Header menunjukkan alamat smart object yang dituju dan sebagai pertanda awal dari paket data. Setelah header, berturutturut enam byte flag posisi tampilan LCD dikirimkan. Masing-masing flag posisi tampilan LCD hanya menggunakan enam bit data pada setiap pengiriman data serial yang dimulai dari bit 5 hingga 0 . Hal ini untuk menghindari kemungkinan header dan flag posisi tampilan LCD memiliki nilai yang sama. Dalam kasus seperti pada gambar 4, terdapat 12 karakter yang ditampilkan. Tail CR Sebagai akhir dari paket data.

\subsection{Desain Skenario}

Supaya dapat digunakan sebagai media interaksi yang alur permainannya diatur dalam semantic connection, smart object harus bersifat universal device. Smart object sebenarnya hanya berupa perangkat masukan dan keluaran. Semua proses skenario diatur pada sebuah server PC. Berbagai skenario dapat diterapkan asalkan sesuai dengan kemampuan yang dimiliki smart object dan mempunyai protokol komunikasi yang sama. Pada Gambar 7 ditunjukkan hubungan antara smart object dan skenario yang dibangun di server PC.

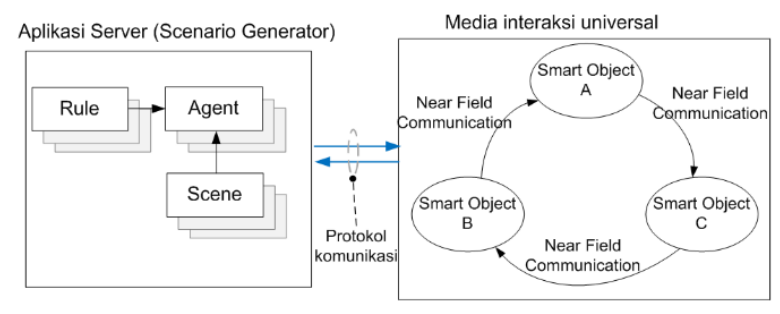

Gambar 7. Hubungan antara media interaksi smart object dan skenario

Sebagai contoh dibangun sebuah skenario permainan sederhana. Permainan diberi nama "Putri Jelita Menunggu Pangeran". Smart object dapat diibaratkan sebagai karakter siluman, satria, dan putri. Siluman dan satria bertanding untuk memperebutkan putri. Masingmasing dapat melukai dan bahkan membunuh dengan cara memukul hingga nyawa habis. Sedangkan untuk mendapatkan cinta putri, harus melakukan pendekatan dengan cara berinteraksi. Pada waktu mendekati putri ada kemungkinan diserang lawan dari samping. Dalam waktu yang ditentukan, siapa yang lebih sering berinteraksi dengan putri, maka dia yang akan mendapatkan putri tersebut. Sebagai ilustrasi dapat dilihat pada Gambar 8.

Putri memiliki sifat pemalu dan pasif. Putri hanya diam menunggu dan berharap ada pria mendekatinya. Siluman dengan sifat yang jahat mempunyai kesaktian bermaksud memperistri putri. Sedangkan satria dengan kesaktian yang sama juga ingin memperistri putri.

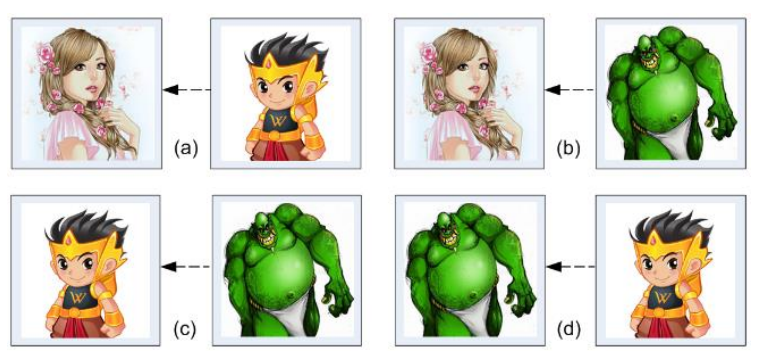

Gambar 8. Skenario permainan "Putri Jelita Menunggu Pangeran” 
(a). Satria melakukan pendekatan kepada putri.

(b). Siluman melakukan pendekatan kepada putri.

(c). Siluman menyerang satria.

(d). Satria menyerang siluman

Informasi yang diperlukan oleh server adalah data identitas smart object yang berada di samping. Ketika terjadi pendekatan terhadap putri atau penyerangan terhadap satria atau siluman, maka secara teknis sebenarnya terjadi pengiriman data antar smart object. Data yang dikirim berupa data identitas karakter yang diserang. Keluaran yang diberikan ke smart object berupa tampilan seperti pada Gambar 9 .

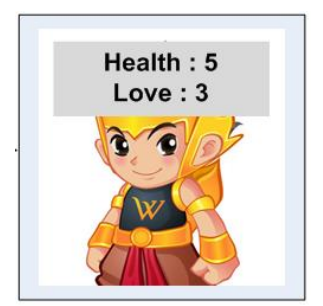

Gambar 9. Keluaran yang ditampilkan pada karakter satria

Rule yang dirancang pada aplikasi server untuk karakter satria ditunjukkan pada gambar 10. Smart object $A$ dianggap sebagai karakter satria, smart object $B$ dianggap sebagai karakter siluman dan smart object $C$ dianggap sebagai karakter putri.

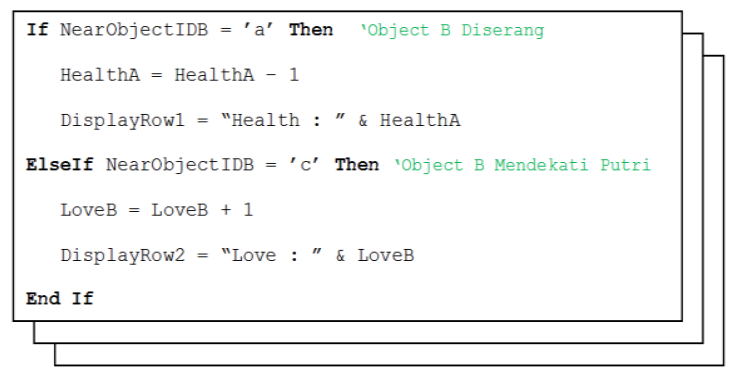

Gambar 10. Rule yang dibangun dalam permainan Putri Jelita Menunggu Pangeran

\section{HASIL DAN PEMBAHASAN}

Proses pengiriman data dari smart object ke server dan sebaliknya perlu diuji untuk mengetahui seberapa besar tingkat kesalahan yang dihasilkan. Baudrate yang digunakan sebesar 4800 bps. Pada tabel 1 disajikan hasil pengujian pengiriman data dari smart object ke server. 2000 paket data yang diterima server diuji untuk mengetahui apakah ada kegagalan sistem dalam mengirim atau menerima data.

Tabel 1. Hasil Pengujian Tingkat Kesalahan Pengiriman Data dari Smart Object Ke Server dengan Variasi Jarak

\begin{tabular}{|c|c|c|c|c|c|c|}
\hline \multirow{2}{*}{$\begin{array}{c}\text { Jarak } \\
(\mathrm{cm})\end{array}$} & \multicolumn{2}{|c|}{$\begin{array}{c}\text { Jumlah smart } \\
\text { object }=1\end{array}$} & \multicolumn{2}{c|}{$\begin{array}{c}\text { Jumlah smart } \\
\text { object }=2\end{array}$} & \multicolumn{2}{c|}{$\begin{array}{c}\text { Jumlah smart } \\
\text { object }=3\end{array}$} \\
\cline { 2 - 7 } & $\begin{array}{c}\text { Waktu } \\
(\mathrm{s})\end{array}$ & $\begin{array}{c}\% \\
\text { Error }\end{array}$ & $\begin{array}{c}\text { Waktu } \\
(\mathrm{s})\end{array}$ & $\begin{array}{c}\% \\
\text { Error }\end{array}$ & $\begin{array}{c}\text { Waktu } \\
(\mathrm{s})\end{array}$ & $\begin{array}{c}\% \\
\text { Error }\end{array}$ \\
\hline 30.00 & 200.30 & 0.00 & 203.43 & 1.50 & 205.92 & 2.67 \\
\hline 60.00 & 200.30 & 0.00 & 204.99 & 2.33 & 204.47 & 2.00 \\
\hline 90.00 & 200.30 & 0.00 & 203.12 & 1.25 & 205.35 & 2.40 \\
\hline 120.00 & 200.63 & 0.00 & 203.58 & 1.48 & 206.03 & 2.77 \\
\hline 150.00 & 200.62 & 0.10 & 202.66 & 1.13 & 205.21 & 2.32 \\
\hline 200.00 & 200.85 & 0.15 & 202.97 & 1.23 & 205.51 & 2.52 \\
\hline 300.00 & 200.31 & 0.05 & 203.27 & 1.35 & 205.51 & 2.52 \\
\hline
\end{tabular}

Dari Tabel 1 terlihat bahwa pengiriman paket data dari smart object ke server mempunyai persentase kesalahan maksimal $2.77 \%$. Ketika hanya satu smart object yang aktif, persentase kesalahan maksimal $0.15 \%$. Jika smart object yang aktif bertambah, persentase kesalahan juga bertambah. Begitu pula dengan waktu yang dibutuhkan untuk pengiriman 2000 paket data dari masing-masing smart object menjadi semakin lama jika jumlah smart object yang aktif betambah. Smart object dalam kondisi aktif berarti smart object mengirimkan data. Ketika banyak smart object yang aktif, paket data akan menumpuk dan terjadi antrian. Hal ini mengakibatkan proses pengiriman menjadi lebih lama dan rentan terhadap kesalahan.

Hasil pengujian pengiriman data dari server ke smart object disajikan pada Tabel 2. 500 data yang diterima smart object diuji untuk mengetahui apakah ada kegagalan sistem dalam mengirim atau menerima data. Dari hasil percobaan pada Tabel 2 terlihat kesalahan yang dihasilkan sangat kecil. Dapat dikatakan bahwa hampir tidak ada data yang hilang.

Waktu pengiriman 500 paket data cukup stabil, yaitu berkisar antara 155.6 hingga 160.3 detik. Mengacu pada rancangan program, server mengirimkan paket data setiap $300 \mathrm{~ms}$. Pengiriman 500 paket data seharusnya membutuhkan waktu 150 detik. Ada selisih 5.6 hingga 8.7 detik dari waktu pengiriman yang seharusnya. Selisih tersebut terjadi karena digunakan untuk pengiriman data melalui udara atau nirkabel. 
Tabel 2. Hasil Pengujian Tingkat Kesalahan Pengiriman Data Dari Server Ke Smart Object Dengan Variasi Jarak

\begin{tabular}{|c|c|c|c|}
\hline $\begin{array}{l}\text { Jarak } \\
(\mathrm{cm})\end{array}$ & $\begin{array}{c}\text { Jumlah Smart } \\
\text { Object }\end{array}$ & $\begin{array}{l}\text { Rata-rata } \\
\text { waktu (s) }\end{array}$ & $\begin{array}{c}\text { Rata-rata } \\
\text { Error } \%\end{array}$ \\
\hline \multirow{3}{*}{30} & 1 & 155.6 & 0 \\
\hline & 2 & 155.6 & 0 \\
\hline & 3 & 155.6 & 0 \\
\hline \multirow{3}{*}{60} & 1 & 160.3 & 0 \\
\hline & 2 & 155.6 & 0 \\
\hline & 3 & 155.6 & 0 \\
\hline \multirow{3}{*}{90} & 1 & 155.7 & 0 \\
\hline & 2 & 155.7 & 0 \\
\hline & 3 & 155.7 & 0 \\
\hline \multirow{3}{*}{120} & 1 & 155.6 & 0 \\
\hline & 2 & 155.65 & 0 \\
\hline & 3 & 155.7 & 0 \\
\hline \multirow{3}{*}{150} & 1 & 155.7 & 0 \\
\hline & 2 & 155.65 & 0 \\
\hline & 3 & 155.7 & 0 \\
\hline \multirow{3}{*}{200} & 1 & 155.7 & 0 \\
\hline & 2 & 155.65 & 0 \\
\hline & 3 & 155.7 & 0 \\
\hline \multirow{3}{*}{300} & 1 & 155.7 & 0 \\
\hline & 2 & 155.7 & 0 \\
\hline & 3 & 155.7 & 0.067 \\
\hline
\end{tabular}

\section{KESIMPULAN}

Makalah ini menyajikan platform komunikasi pada smart object yang digunakan untuk membangun skenario permainan. Dari hasil pengujian diperoleh hasil yang baik dengan tingkat kesalahan dibawah $3 \%$. Semakin banyak jumlah smart object yang mengirimkan data ke server, maka semakin besar pula kesalahan pengiriman data yang dihasilkan. Terbukti dari hasil pengujian, pengiriman data yang melibatkan satu smart object menghasilkan kesalahan hingga $0.15 \%$. Sedangkan pengiriman data yang melibatkan tiga smart object menghasilkan kesalahan hingga $2.77 \%$.

\section{DAFTAR PUSTAKA}

[1] G. Burdea, T. Blois, E. Ching, J. Halton, B. Lopetinsky, and V. Drysdale, "Tutorial 1: Nintendo Wii-based rehabilitation", in Virtual Rehabilitation, 2008.

[2] R.S.Leder, G. Azcarate, R. Savage, S. Savage, L.E. Sucar, D. Reinkensmeyer, C. Toxtli, E. Roth, and A. Molina, "Nintendo Wii remote for computer simulated arm and wrist therapy in stroke survivors with upper extremity hemipariesis", in Virtual Rehabilitation, 2008.

[3] P. Orlando R. E, R. Joel J. P. C, dan G. Abel J. P, "Contributions of Sensor Networks to
Improve Gaming Experience", IEEE 24th International Conference on Advanced Information Networking and Applications Workshops, 2010, hal. 1047-1052.

[4] E. Akihiro dan T. Craig, "Towards A Semantic World : Smart Objects In A Virtual World", University of Arkansas, 2011, Vol 3, hal.905-911.

[5] K. Gerd, K. Fahim, F. Daniel, dan S. Vasughi, "Smart Objects as Building Blocks for the Internet of Things", Internet of things Track, eds. T. Frederic, dan M. Florian, 2010, hal.30-37.

[6] M. Weiser, "The computer for the 21st century, in Scientific America",1991, Vol 265, No3, hal.94-104.

[7] I. Michita, H. Yutaka, S. Satoru dan K. Hideyuki, "Semantic Connection between Everyday Objects and a Sensor Network", Keio University, 2010.

[8] W. Maas, dan U. Varshney,Preface to the Focus Theme Section : "Smart Products", Electronic Markets, 2008, vol. 18, no.3, hal. 211-215.

[9] N. Streitz, "Designing Smart Artifacts for Smart Environments," Computer, 2005, vol. 38, no. 3, hal. 41-49

[10] W. Iwan Kurnianto, H. Mochamad, dan Christyowidiasmoro, "Implementasi Metode Complementary Filter untuk Estimasi Orientasi Pada Smart Object", Sentia, 2013, vol. 5 ISSN:2085-2347, hal A138-142.

[11] D. Yun, J. Kang, J. Kim, and D. Kim, "A Body Sensor Network Platform with TwoLevel Communications", in IEEE Int. Symposium on Consumer Electronics (ISCE 2007), Irving, TX, USA, 2007, hal. 1-6

[12] Z. R Fathur, "Implementasi Jaringan Sensor Nirkabel Menggunakan Zigbee pada Monitoring Tabung Inkubator Bayi", JNTE Universitas Andalas Vol: 5 No.2, Juli 2016

\section{Biodata Penulis}

Iwan Kurnianto Wibowo, lahir di Malang 30 Desember 1987. Menyelesaikan studi S2 Teknologi Permainan Jurusan Teknik Elektro Institut Teknologi Sepuluh Nopember tahun 2013. Saat ini penulis mengajar di Program Studi Teknik Komputer Politeknik Elektronika Negeri Surabaya. 